\title{
Estimation of Lake Outflow from the Poorly Gauged Lake Tana (Ethiopia) Using Satellite Remote Sensing Data
}

\author{
Zheng Duan ${ }^{1}$ (1) , Hongkai Gao ${ }^{2,3,4, *(\mathbb{D})}$ and Changqing Ke ${ }^{5,6,7}$ \\ 1 Chair of Hydrology and River Basin Management, Technical University of Munich, Arcisstrasse 21, \\ 80333 Munich, Germany; zheng.duan@tum.de \\ 2 Key Laboratory of Geographic Information Science (Ministry of Education), East China Normal University, \\ Shanghai 200241, China \\ 3 School of Geographic Sciences, East China Normal University, Shanghai 200241, China \\ 4 Key Laboratory for Mountain Hazards and Earth Surface Process, Institute of Mountain Hazards \\ and Environment, Chinese Academy of Sciences, Chengdu 610041, China \\ 5 Jiangsu Provincial Key Laboratory of Geographic Information Science and Technology, Nanjing University, \\ Nanjing 210023, China; kecq@nju.edu.cn \\ 6 Key Laboratory for Satellite Mapping Technology and Applications of State Administration of Surveying, \\ Mapping and Geoinformation of China, Nanjing University, Nanjing 210023, China \\ 7 Collaborative Innovation Center of Novel Software Technology and Industrialization, Nanjing 210023, China \\ * Correspondence: hkgao@geo.ecnu.edu.cn; Tel.: +86-153-0160-8750
}

Received: 22 May 2018; Accepted: 25 June 2018; Published: 4 July 2018

\begin{abstract}
Lake Tana is the largest lake in Ethiopia, and its lake outflow is the source of the Blue Nile River that provides vital water resources for many livelihoods and downstream/international stakeholders. Therefore, it is essential to quantify and monitor the water balance of Lake Tana. However, Lake Tana is poorly gauged, with more than $50 \%$ of Lake Tana Basin being ungauged from in-situ measurements, making it difficult to quantify the lake inflow from surrounding basins. The lack of in-situ measurements highlights the need for the innovative application of satellite remote sensing. This study explores how freely accessible satellite remote sensing can be used to complement routine weather data to quantify the water balance of Lake Tana and its surrounding catchments. This study particularly investigates whether the outflow from Lake Tana can be estimated with sufficient accuracy as the residual of the lake water balance. Monthly inflow into lake was computed as the total runoff from the surrounding catchments; the runoff was estimated as the residual of the land-based catchment water balance using satellite precipitation improved with an integrated downscaling-calibration procedure, satellite evapotranspiration, and a correction term for changes in land total storage (soil moisture storage and deep percolation). The outflow from Lake Tana was estimated as the residual of lake water balance by combining satellite-based lake precipitation, changes in water storage, and lake inflow with estimated lake evaporation. Evaluation using limited available measurements showed that estimated annual runoff for two gauged subbasins agreed well with measurements, with differences within $4 \%$. The estimated annual outflow from Lake Tana was also close to measured outflow, with a difference of $12 \%$. However, the estimated monthly runoff from catchments and monthly lake outflow were unsatisfactory, with large errors.
\end{abstract}

Keywords: Lake Tana; reservoir; water balance; ungauged; Blue Nile; integration

\section{Introduction}

The water stored in lakes and reservoirs plays a vital role in the economic development and many services that contribute to the well-being of communities up to kilometers downstream 
(even across administrative borders) and in close proximity to lakes and reservoirs [1]. A solid understanding and quantification of the water balance of lakes and reservoirs is essential for many applications, including hydrological modelling, effective water resources management, and climate change studies, etc. To achieve the quantification of the water balance of lakes and reservoirs, relevant data on each component (inflow, precipitation, water level/volume, and outflow, etc.) are required, ideally from ground measurements. However, such required data are often not readily available because of, for example, the following situations: (1) variables are not measured at all, which is the case in ungauged basins and inaccessible regions; or (2) measured data are not freely shared. The surface outflow from lakes and reservoirs, a measure of water supply, is a particular variable of high importance for downstream multiple sectors. Unfortunately, the responsible agencies for lake, reservoir, and dam operations are usually not keen to share these outflow data with other agencies and neighboring countries [2]. Because of the strategic importance of stored water resources in lakes and reservoirs, institutions responsible for dam operations are often not transparent in their reporting. Poor communications and information cause distrust and tension between multiple water use sectors.

The aforementioned situations result in the lack of data, which poses an obstacle for conducting research in certain regions. The scientific communities in hydrology need to figure out how to improve our understanding of hydrological process and prediction in ungauged and poorly gauged basins. The Prediction in Ungauged Basins (PUB) initiative was launched in 2003 and since then, considerable progress has been made to enrich the modelling concepts for a comprehensive description of water processes [3-5]. A detailed review of the achievements of this PUB initiative can be found in [6]. A recent community survey among 336 hydrologists [7] revealed an increasing necessity to adopt parsimonious approaches for advanced hydrologic monitoring due to the lack of a dense measuring stations network, in particular in ungauged basins or poorly gauged basins. In many circumstances, satellite observations are the only data source available to the modelers, but the ground monitoring approach should be assessed as a valuable tool for calibration of the different parameters involved in the satellite system. In order to improve our understanding of the hydrological cycle at various scales and in poorly and ungauged basins, more monitoring and observations are indeed necessary. For this, a feasible and promising direction is to promote the innovations and multi-disciplinary perspectives in designing low-cost equipment and in developing or combining monitoring techniques. This direction has been implemented in practice through the establishment of a new working group in 2013, the Measurements and Observations in the XXI century (MOXXI), which targets innovation in all realms of hydrological observations from ground-based to remote sensing. A new review [3] summarizes the major achievements of MOXXI and outlines relevant challenges and opportunities. Our current study focused on the application of satellite remote sensing as a monitoring technique for studying the water balance of a poorly gauged lake.

Satellite remote sensing has been demonstrated to be capable of monitoring various water balance components over land and water. For precipitation, many satellite precipitation databases have been generated and widely used [8,9]. For terrestrial evapotranspiration, many models have been proposed to estimate regional and/or global terrestrial evapotranspiration from satellite observations [10-13]. The Gravity Recovery and Climate Experiment (GRACE) mission has made available monthly terrestrial water storage changes from March 2002 [14]. By combing satellite-based estimates of precipitation, actual evapotranspiration, and terrestrial water storage changes, Ref. [15] found that estimates of annual outflow from all 15 subbasins of the Nile Basin were in very good agreement with measurements. This highlights the potential of satellite remote sensing techniques in estimating runoff from surrounding basins into the lake, i.e., lake inflow, which will be further investigated in this study. For water bodies, satellite altimetry has been successfully used to derive the water level in lakes, reservoirs, rivers, and wetlands $[16,17]$. Changes in water storage in inland water bodies can further be well estimated by combing satellite altimetry and satellite imagery data [18-24]. Satellite remote sensing can also provide data for several variables related to the estimation of lake evaporation: solar radiation, surface albedo, and surface temperature. Satellite estimates of water surface temperature and solar radiation have also 
shown good agreements with measurements for several lakes [25]. The same study demonstrated that the developed hysteresis model can be applied together with satellite measurements to estimate heat storage changes, thereby supporting the computation of evaporation from open water bodies based on energy balance equations.

Many studies have been conducted to analyze the water balance of certain lakes [26,27]. However, to our best knowledge, very few studies integrated the various satellite remote sensing-based techniques mentioned above for the quantification of the water balance of lakes and reservoirs and in particular for the estimation of lake outflow. Specifically, Ref. [2] quantified the water balance of Lake Victoria in East Africa and estimated the outflow using satellite remote sensing data and limited ground measurements. In their study, the changes in lake level were estimated from satellite altimetry data; precipitation over land catchments and the lake were estimated from TRMM 3B43 monthly data; lake evaporation was estimated using the bulk aerodynamic formulae with input from ECMWF operational analyses and satellite-derived products; and lake surface inflows were modelled as being proportional to precipitation and lake subsurface flows were modelled as being proportional to the water storage changes derived from GRACE data. During modelling of the lake surface and subsurface inflow, the measured outflow was used to determine several associated coefficients. After the coefficients were determined, the authors further estimated lake outflow as a residual in the water balance, but they found large errors in the estimated outflow and concluded that currently available satellite data were not sufficiently accurate to estimate the monthly outflow from Lake Victoria as a residual. However, they found that the water balance of a downstream lake, Lake Kyoga, is strongly influenced by inflow from Lake Victoria, and they further proposed a method to estimate outflow from Lake Victoria by examining the water balance of Lake Kyoga. The applicability of the proposed method might be only limited to Lake Victoria or other similar lakes with a small downstream lake [28]. Ref. [29] used measured inflow data and satellite-based estimates of water volume to estimate monthly surface outflow as a residual of the water balance in Lake Nasser and Roseires Reservoir in the Nile Basin. They found that estimated outflow showed acceptable agreement (RMSE is $18 \%$ of measurement) with measured outflow for Roseries Reservoir, but unacceptably large errors in the estimated outflow were found for Lake Nasser. Recently, Ref. [28] used a combination of satellite altimetry and a satellite precipitation product TRMM 3B42 to estimate reservoir surface outflow for two small reservoirs: Hungry Horse Reservoir in northwest U.S. and Kaptai Reservoir in Bangladesh. The reservoir outflow was estimated as a residual of only three components, i.e., changes in reservoir storage, precipitation-induced reservoir inflow, and reservoir evaporation, without considering precipitation over reservoirs. The reservoir inflow was estimated from the curve number $(\mathrm{CN})$ method and the Variable Infiltration Capacity (VIC) model without local calibration, and using the VIC derived reservoir inflow yielded better reservoir outflow. They found that the estimated annual outflow was reasonable, with an overall relative RMSE of $20 \%$ and $26 \%$ for Kaptai Reservoir and Hungry Horse Reservoir, respectively, but estimated monthly outflow was unsatisfactory.

The three abovementioned studies suffer from one or more of the following limitations: (1) the existing study used measured lake inflow and outflow as the inputs, which are not readily available; strictly speaking, this should not be a limitation for areas where sufficient data are available. However, the complete data on lake inflow is not even existent for poorly gauged basins, and thus the methods with an intense demand for measured data could not be applied for certain areas; (2) the existing study did not consider a complete water balance equation, which limits the application of that proposed method; (3) the existing study used methods that have been proved with an inferior performance or with large uncertainties for some key water balance components (e.g., lake evaporation and satellite precipitation over land without local calibration). Therefore, the findings may not represent the actual accuracy of estimated lake outflow to the full potential extent. This submitted study focuses on the poorly gauged Lake Tana, which is representative of a poorly gauged area and calls for applications of satellite remote sensing techniques. To address the abovementioned three 
limitations, this study considered a more complete water balance equation, and used proved superior methods for key components. Most importantly, this study only used readily/publicly available data and as many satellite-based methods/data as possible to estimate lake outflow.

Lake Tana is located in the northwestern highlands of Ethiopia (Figure 1). It is the largest lake in Ethiopia and the third largest in the Nile River Basin [30]. Lake Tana is the source of the Blue Nile River, and the Blue Nile River contributes more than $60 \%$ of total flow into the Nile River at Aswan in Egypt [31]. Therefore, sustainable management of the water resources of Lake Tana is of great importance for Ethiopia and other Nile Basin riparian countries. To fulfill this purpose, the water balance of Lake Tana needs to be fully understood. However, the lack of reliable key water balance components hampers quantification of the water balance of Lake Tana and other lakes in the Nile River [32]. In Lake Tana Basin, the gauged catchments cover less than $50 \%$ of the total basin area [33]. For some gauged catchments, runoff data is available, but the data quality is poor. The five general gauged major catchments are shown in Figure 1. Previous studies pointed out that some gauging stations are submerged during the peak flows period (e.g., [32]) and basin outflow also occurs via wetlands that are expanded during the rainy season. These issues lead to a poor quantification of the runoff from the surrounding catchments into the lake body. Previous studies focused on the estimation of total inflow, but there are significant differences in the estimated total lake inflow and the relative contribution of runoff from the ungauged catchments [34]. The classical solution to estimate runoff from ungauged catchments is to use the measured surface outflow from Lake Tana plus other components and inversely infer the inflow from ungauged streams into the lake body assuming zero groundwater outflow. This ensures that the water balance is closed, but it does not mean that all water balance components are properly understood and quantitatively described. Several recent studies used hydrological models to simulate runoff from gauged catchments, and the calibrated parameters in gauged catchments were then transferred to ungauged catchments through various regionalization approaches for estimating the ungauged runoff $[33,34]$. This modelling procedure usually requires long-term streamflow data to be available (often difficult to achieve for certain areas) to warm-up and calibrate the model. In addition, the successful application of regionalization approaches could be challenged because of the possible equifinality problem in the model parameters and contrasting catchment properties [32,35].

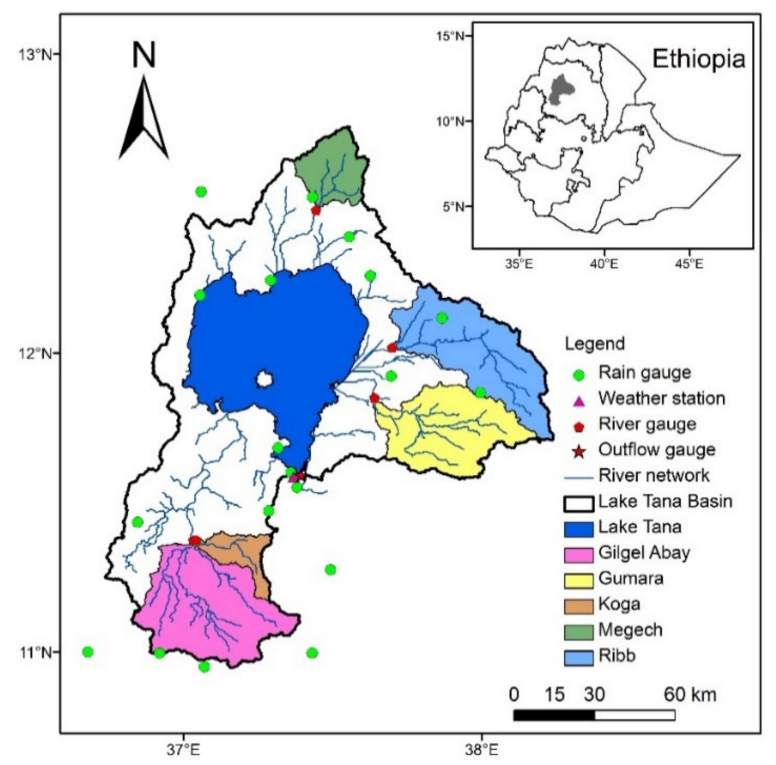

Figure 1. Location of Lake Tana Basin, 20 rain gauges, one weather station, and one outflow gauge. The five gauged major sub-basins are also shown.

The surface outflow from Lake Tana is measured, but the responsible agencies are not keen on sharing these outflow data with other agencies and riparian Nile Basin countries in a transparent manner. Given the fact that the outflow from Lake Tana is the source for the Blue Nile River, 
the downstream stakeholders are eager to get discharge release data for their water uses and management. For this purpose, this study aims to quantify the water balance of Lake Tana and its surrounding basin using satellite remote sensing techniques and limited routine weather measurements. Particularly, we investigate whether the outflow from Lake Tana can be estimated as the residual of the water balance with sufficient accuracy.

This study integrates all innovative methods on individual water balance components in our previous studies $[19,25,36,37]$ for a case study of the water balance of a poorly gauged lake. Compared to previous studies in Lake Tana, the novelty of this study lies in applying state-of-the-art satellite-based methods to estimate most water balance components independently, and considering the whole land area of Lake Tana Basin to estimate total lake inflow; thus the ungauged contribution is included already. In addition, the accuracy of satellite-based estimates of runoff (inflow to lake) and the resulting lake outflow were also evaluated with available in-situ measured data, which adds a particular robustness to our current study.

\section{Study Area}

Lake Tana is a vast circular-shaped and shallow lake with water level fluctuations of approximately $1.6 \mathrm{~m}$ among seasons. The surface water area of Lake Tana ranges from 2966 to around $3100 \mathrm{~km}^{2}$, depending on the seasonal fluctuation of the lake level [19]. The Lake Tana Basin covers a total surface area of about $15,100 \mathrm{~km}^{2}$, including the lake area. The lake area covers approximately $20 \%$ of the total basin area. In the Lake Tana Basin, the elevation ranges from 1791 to $4084 \mathrm{~m}$ above the mean sea level. The main land use classes are cultivated land, pasture, forest, and wetland. Cultivated land accounts for more than $50 \%$ of the total basin area [30]. The mean annual precipitation is approximately $1395 \mathrm{~mm} / \mathrm{yr}$ based on the analysis of available rain gauge data between 1998 and 2004 in previous study [36]. The climate of Lake Tana Basin is tropical highland monsoon with a rainy season (June-September) and a dry season (October-March). The seasonal distribution of rainfall is mainly controlled by the north-south movement of the Inter Tropical Convergence Zone (ITCZ) [38]. The air temperature shows large diurnal, but small seasonal, variability. The mean annual temperature is $20^{\circ} \mathrm{C}$ [30]. As shown in Figure 1, there are several rivers feeding Lake Tana, such as Gilgel Abay, Gumara, Koga, Megech, and Ribb. However, only a very small number and part of these rivers are often gauged. The five gauged major subbasins are also shown in Figure 1. The upper parts of the Gilgel Abay and Gumara basin cover an area of $1656 \mathrm{~km}^{2}$ and $1279 \mathrm{~km}^{2}$, respectively, and both basins were investigated in this study given the availability of needed data.

\section{Materials and Methods}

This study investigated the water balance of Lake Tana for the year 2006 at monthly and annual timescales because of the availability of the measured outflow data for this year. For evaluation purposes, the total lake outflow was estimated as the residual of the water balance equation. Based on the lake water balance, the lake outflow $\left(Q_{0}\right)$ was estimated as:

$$
\mathrm{Q}_{\mathrm{o}}=\mathrm{Q}_{\mathrm{i}}+\mathrm{A}_{\text {lake }}\left(\mathrm{P}_{\text {lake }}-\mathrm{E}_{\text {lake }}\right)+\mathrm{G}_{\mathrm{i}}-\mathrm{G}_{\mathrm{o}}-\mathrm{dV}_{\text {lake }} / \mathrm{dt}
$$

where $Q_{i}$ is the inflow into the lake from the surrounding catchments; $P_{\text {lake }}$ is the precipitation directly over the lake area; $E_{\text {lake }}$ is the lake evaporation; $\mathrm{dV}_{\text {lake }}$ is the change in water storage over the time period dt; $A_{l a k e}$ is the surface area of the lake, which varies with water level; and $G_{i}$ and $G_{o}$ are the groundwater inflow and outflow, respectively. The data and methods used to quantify each component are described in the subsequent sections. 


\subsection{Inflow into the Lake $\left(Q_{i}\right)$}

The total inflow into Lake Tana was estimated as the surface runoff (Runoff land) using the simple water balance equation of the land area surrounding the lake:

$$
\mathrm{Q}_{\mathrm{i}}=\text { Runoff }_{\text {land }}=\mathrm{P}_{\text {land }}-\mathrm{ET}_{\text {land }}-\mathrm{dS}_{\text {land }} / \mathrm{dt}
$$

where, $\mathrm{P}_{\text {land }}$ is the precipitation over the land area of the Lake Tana Basin, $\mathrm{ET}_{\text {land }}$ is the actual evapotranspiration, and $\mathrm{dS}_{\text {land/dt }}$ is the change in the total water storage over the land area during a month time period $\mathrm{dt}$. The groundwater component is neglected in this equation based on reasons specified in Section 3.5 .

\subsubsection{Precipitation $\left(\mathrm{P}_{\text {land }}\right)$}

A pre-requisite for estimating the inflow to lakes and reservoirs from the surrounding catchments is to have access to accurate precipitation data at a high spatial resolution and for the mountains where gauges are often absent. In this study, monthly total rainfall data from 20 rain gauge stations for the year 2006 were obtained from the Ethiopian National Meteorological Agency (ENMA). The locations of the 20 rain gauge stations are shown in Figure 1. In addition to that, the Version 7 TRMM (Tropical Rainfall Measuring Mission) 3B43 monthly precipitation data [39] were obtained from http:/ / mirador.gsfc.nasa. gov to get estimates of aerial rainfall volumes. The TRMM 3B43 data are at a $0.25^{\circ}$ spatial resolution. The satellite precipitation data have a bias and require local calibration. In this study, the integrated downscaling and calibration procedure developed by [36] was used to combine the advantages of both satellite precipitation and all 20 available rain gauge stations data to generate monthly precipitation at a $1 \mathrm{~km}$ spatial resolution for Lake Tana Basin. This procedure is based on an integration of the TRMM 3B43 precipitation product (at $0.25^{\circ}$ resolution) and NDVI (Normalized Difference Vegetation Index) from SPOT-Vegetation satellite data at a $1 \mathrm{~km}$ resolution for spatial downscaling first, followed by local calibration using rain gauge data. The spatial downscaling from $0.25^{\circ}$ to $1 \mathrm{~km}$ grids was first performed for the annual precipitation from the original TRMM3B43 by using site-specific non-linear relationships between annual precipitation and annually averaged NDVI. The downscaled $1 \mathrm{~km}$ annual precipitation grids were then calibrated using the Geographical Difference Analysis (GDA) calibration method. The GDA was used to minimize the difference between the downscaled precipitation and measurements from all available rain gauge stations. The annual calibrated $1 \mathrm{~km}$ precipitation grids were further disaggregated to monthly precipitation using the monthly fractions derived from the original TRMM3B43 data. This integrated downscaling and calibration procedure has been successfully tested in Lake Tana Basin in Ethiopia with a humid climate and the Caspian Sea Region in Iran with a semi-arid climate [36].

\subsubsection{Actual Evapotranspiration ( $\left.\mathrm{ET}_{\text {land }}\right)$}

The actual evapotranspiration data at a $1 \mathrm{~km}$ spatial resolution and monthly timescale for Lake Tana Basin were obtained using the ETLook remote sensing model [10]. The ETLook data can be obtained from eLEAF (https:/ / eleaf.com/). The ETLook model has been validated and shown to generate $\mathrm{ET}_{\text {land }}$ values with good agreement with ground measurements in many different climate systems and land use classes. Due to persistent cloud cover, ETLook has some comparative advantages over other ET models. The algorithm relies substantially on surface soil moisture values from AMSR-E, NDVI from MODIS, and solar radiation from Meteosat Second Generation. Only monthly ET $\mathrm{E}_{\text {land }}$ values from ETLook for the year 2007 were available for direct usage in this study. In addition, the monthly actual ET values at the $1 \mathrm{~km}$ spatial resolution from the Operational Simplified Surface Energy Balance (SSEBop) model $[13,40,41]$ were collected for the year 2006 and 2007. The monthly actual SSEBop-derived ET can be freely downloaded from https: / / earlywarning.usgs.gov/. The SSEBop model uses a simplified calculation procedure using thermal measurements of MODIS. Initial comparison of monthly SSEBop-derived $\mathrm{ET}_{\text {land }}$ values between the year 2006 and 2007 showed that the seasonal temporal patterns are similar $\left(R^{2}=0.83\right.$ 
and RMSE $=11 \mathrm{~mm} / \mathrm{month}$ ) although the absolute values differ (results are not shown for conciseness). The annual total SSEBop-derived $\mathrm{ET}_{\text {land }}$ values averaged over the land area of Lake Tana Basin were 581 and $513 \mathrm{~mm} / \mathrm{yr}$ for the years 2006 and 2007, respectively. Given the comparative advantages of the ETLook model mentioned in [15], this study used a similar simple correction factor to obtain monthly actual ET based on available ETLook data and the annual and monthly ratios derived from SSEBop-derived ET data The annual ratio of $1.13(581 / 513)$ from SSEBop was derived. The monthly ratios have also been determined for each individual month. The ETLook-derived $\mathrm{ET}_{\text {land }}$ values for 2007 were corrected with the fractional $\mathrm{ET}_{\text {land }}$ changes of the SSEBop model for 2006 and 2007, following [15].

\subsubsection{Changes in the Water Storage over Land Area $\left(\mathrm{dS}_{\text {land }} / \mathrm{dt}\right)$}

The water storage changes are expected to be significant at monthly timescales. Therefore, the term $\mathrm{dS}_{\text {land }} / \mathrm{dt}$ is necessary to assess reasonable runoff from land to the lake body. The total water storage changes include storage changes of soil moisture, groundwater, canopy, snow and ice, and surface water. Such total water storage changes data can be derived from GRACE data, but the coarse resolution of GRACE data might make it reasonably suitable for areas of $200,000 \mathrm{~km}^{2}$ and larger [23]. Additionally, the water storage changes in Lake Tana are expected to considerably affect the signal of GRACE due to the relatively large size of Lake Tana ( $20 \%$ of the total basin area), which makes it difficult to extract the required water storage changes in the exclusive land surface. Therefore, given the aforementioned two issues, we did not use GRACE data in Lake Tana Basin in this study. There is no snow or ice on the tropical basin, and the canopy and surface water storage over the land areas of Lake Tana Basin is not considerable, and therefore was neglected in this study.

For soil moisture storage changes, we used the output from GLDAS (Global Land Data Assimilation System) in this study. GLDAS drives four land surface models to provide estimates of various land surface parameters, including soil moisture. The forcing data are from various satellite-derived precipitation, radiation data, and atmospheric analysis-based products [42]. The data are freely available from http:/ / mirador.gsfc.nasa.gov. The highest spatial resolution of the product is $0.25^{\circ}$ and generated by the Noah model [43]. The latter data set from Noah at a monthly scale was used in this study. The Noah data contain four-layers of average soil moisture; the total considered soil column depth is $200 \mathrm{~cm}$. Fourteen monthly average soil moisture data were obtained for the period from December (2005) to January (2007). For each month, four layers of average soil moisture were summed up to obtain the average total soil moisture. The monthly average total soil moisture was assumed to represent the 15th day of each month. The soil moisture on the first day of each month was derived by linear interpolation of the two consecutive monthly values. Finally, the changes in soil moisture for each month were computed as the difference in the derived average total soil moisture between the first day of the following month and the current month.

With respect to groundwater storage change, several studies have shown deep percolation to occur in Lake Tana Basin $[30,44,45]$. In a World Bank report, [45] provided the average annual water balance of four gauged catchments (Gilgel Abay, Gumara, Ribb, and Megetch, see Figure 1) of Lake Tana Basin for the period 2000-2004. The annual average deep percolation for the four catchments of Lake Tana Basin ranged from 54 to $343 \mathrm{~mm} / \mathrm{yr}$. This suggests that a certain amount of deep percolation water loss has to be considered to reflect the real situation occurring in Lake Tana Basin. The area weighted average value of annual deep percolation of four catchments provided by [45] was computed to be $154 \mathrm{~mm} / \mathrm{yr}$. For the entire Lake Tana Basin, much higher percolation values were reported by [30] using the hydrological model SWAT. For the SWAT model calibration period 1981-1992, the annual average percolation value was determined to be $251 \mathrm{~mm} / \mathrm{yr}$, or $21.5 \%$ of the annul precipitation of $1168 \mathrm{~mm} / \mathrm{yr}$. For the more recent validation period 1993-2004, the annual average percolation was found to be $400 \mathrm{~mm} / \mathrm{yr}$ or $28.7 \%$ of the annul precipitation of $1394 \mathrm{~mm} / \mathrm{yr}$. The high percolation values have been commonly reported in many studies of the upper Nile Basins [15,46-48]. Without other data to independently estimate the deep percolation in this study, the average value (i.e., $325 . \mathrm{mm} / \mathrm{yr}$ ) of the two reported values from [30] was used to quantify the deep percolation for the whole land area of 
Lake Tana Basin. The annual deep percolation has been partitioned into monthly values according to the monthly distribution of $\left(\mathrm{P}_{\text {land }}-\mathrm{ET}_{\text {land }}\right)$ values; for a given month with $\left(\mathrm{P}_{\text {land }}-\mathrm{ET}_{\text {land }}\right)>0$, the monthly deep percolation was estimated by multiplying the annual deep percolation value with the ratio of $\left(\mathrm{P}_{\text {land }}-\mathrm{ET}_{\text {land }}\right)$ in that month to the sum of $\left(\mathrm{P}_{\text {land }}-\mathrm{ET}_{\text {land }}\right)$ from such months. We acknowledged that this could be a source for introducing uncertainty to the monthly deep percolation, which needs to be investigated in future studies.

The monthly runoff from all catchments into Lake Tana was estimated from rainfall surplus (difference between precipitation and ET) corrected for soil moisture storage change and deep percolation. The reliable monthly measured runoff data in two large gauged catchments (Gilgel Abay and Gumara, see Figure 1) were obtained from the Ministry of Water Resources (MoWR) in Ethiopia. Before estimating the runoff from the whole land area, we estimated monthly runoff for these two gauged catchments and evaluated the results with measured data. The annual deep percolation values for the two gauged catchments were taken from [45] and monthly values were assigned in the same way as described above.

\subsection{Precipitation over the Lake $\left(P_{\text {lake }}\right)$}

Precipitation falling directly on the water surface can be measured by installing rain gauges over lakes and reservoirs. For large lakes and reservoirs, more than one gauge is needed to reasonably determine the spatial average precipitation. However, such measurements are often lacking. For most lakes and reservoirs, there are no gauging stations installed over the surface at all. As a result, it is still common practice to use precipitation measured in the nearby land or shoreline to determine lake precipitation. For this purpose, either directly measured precipitation data from one land-based gauge station or interpolated precipitation data from several available nearby stations are used [34]. However, previous studies showed that for large lakes, the nocturnal lake-breeze effects can markedly enhance rainfall over the center of the lake, and hence the nearby land-based rainfall could considerably underestimate precipitation over the lake $[49,50]$.

Satellite remote sensing can provide precipitation data over the water surface by measuring the atmospheric conditions in terms of precipitable water. Ideally, satellite-based precipitation data require a local calibration, as mentioned in Section 3.1.1, but without rain gauges installed over water surfaces, it is impossible to conduct a decent calibration. The original satellite precipitation data have been used to quantify precipitation over the lake in many studies, e.g., [2,51] for Lake Victoria and [52] for Lake Turkana. In this study, none of the available 20 rain gauge stations are located over the lake surface, and only five stations are located relatively near the shoreline (Figure 1). Considering the relatively large surface area of Lake Tana, the sparse land-based rain gauge stations may be insufficient to represent the average rainfall over the lake surface. Therefore, in this study, the average precipitation over Lake Tana was computed from the original satellite precipitation data (in this study monthly TRMM 3B43) following the aforementioned studies [2,51,52].

\subsection{Evaporation from the Lake ( $\left.E_{\text {lake }}\right)$}

Daily routine weather data (air temperature, actual duration of sunshine, relative humidity, wind speed) were taken from the Bahir Dar weather station (Figure 1) through the ENMA. The De Bruin-Keijman (DK) model [53] was used to estimate lake evaporation in this study. The DK model was selected because it has a low input data requirement and generally provides better evaporation estimates than the classical Penman model [37]:

$$
\mathrm{E}=\frac{\Delta\left(\mathrm{Rn}-\mathrm{Q}_{\mathrm{t}}\right)}{0.85 \Delta+0.63 \gamma} \times \frac{86.4}{\lambda \rho_{\mathrm{w}}}
$$

where, $\mathrm{E}$ is the evaporation rate $\left(\mathrm{mm} \mathrm{d}^{-1}\right), \Delta$ is the slope of the saturated vapor pressure-temperature curve at air temperature $\left(\mathrm{kPa}^{\circ} \mathrm{C}^{-1}\right)$, and $\gamma$ is the psychrometric constant $\left(\mathrm{kPa}^{\circ} \mathrm{C}^{-1}\right)$ that varies with 
the atmospheric pressure. The atmospheric pressure can be approximated as a function of altitude [54], and the altitude of $1788 \mathrm{~m}$ above the mean sea level was used for Lake Tana in this study. $\lambda$ is the latent heat of vaporization $\left(2.45 \mathrm{MJ} \mathrm{kg}^{-1}\right), \rho_{\mathrm{W}}$ is the density of water $\left(1000 \mathrm{~kg} \mathrm{~m}^{-3}\right), \mathrm{Rn}$ is the net radiation $\left(\mathrm{W} \mathrm{m}^{-2}\right)$, and $\mathrm{Q}_{\mathrm{t}}$ is the heat storage change $\left(\mathrm{W} \mathrm{m}^{-2}\right)$. The value for net radiation $\mathrm{R}_{\mathrm{n}}$ was computed using Slob's equation with the original coefficient [55].

$$
\mathrm{Rn}=(1-\alpha) \operatorname{Rs}-110 \frac{\mathrm{Rs}}{\mathrm{Ra}}
$$

where Rs is the shortwave solar radiation $\left(\mathrm{W} \mathrm{m}^{-2}\right)$, Ra is the extraterrestrial radiation $\left(\mathrm{W} \mathrm{m}^{-2}\right)$, and $\alpha$ is the albedo of the water surface. An albedo of 0.05 was used in this study. The computation of Ra is purely theoretical, and is based on the latitude and the day of the year (DOY), as described in [54]. The value for Rs has been determined from actual hours of sunshine. It can alternatively be derived from cloud cover measurements of the geostationary MSG satellite. The simple Slob's equation with a constant albedo of 0.05 and default coefficient of $110 \mathrm{~W} \mathrm{~m}^{-2}$ has been found to perform reasonably well in estimating $\mathrm{Rn}$ for 12 lakes [25]. The solar radiation Rs was computed using the Angstrom formula with the recommended Angstrom coefficients. This formula relates Rs to extraterrestrial radiation Ra and relative sunshine duration, which is described as [54]:

$$
\mathrm{Rs}=\left(0.25+0.50 \frac{\mathrm{n}}{\mathrm{N}}\right) \mathrm{Ra}
$$

where, $\mathrm{n}$ is the actual duration of sunshine (hours); and $\mathrm{N}$ is the maximum possible duration of sunshine or daylight hours, which can be computed from the latitude and the day of the year.

Our developed empirical procedure [25] was adopted to estimate the heat storage change $Q_{t}$ from $\mathrm{Rn}$ and water surface temperature in this study. The measured monthly mean water temperature data for Lake Tana were provided by [56]. They measured water temperature at several different depths during two periods: 1991-1993 and 1999-2000. Ref. [57] mentioned that such water temperature data can be considered as the surface temperature. Following [57], the monthly temperature data during the period 1999-2000 (most recent to the studied year) by [56] were also used as the water surface temperature in this study by assuming limited inter-annual variation in the water surface temperature. We acknowledge that this assumption would introduce a certain degree of uncertainty. The heat storage change equation tailored for local conditions was determined for Lake Tana as a function of $\mathrm{Rn}$ and its time derivative $\mathrm{dRn} / \mathrm{dt}[25]$ :

$$
\mathrm{Q}_{\mathrm{t}}=1.51 \mathrm{Rn}-223.88-4.36 \mathrm{dRn} / \mathrm{dt} .
$$

The monthly $\mathrm{Q}_{t}$ values $\left(\mathrm{W} \mathrm{m}^{-2}\right.$ ) were estimated from Rn using Equation (6), and the DK model was applied to compute the monthly open water evaporation from Lake Tana for the year 2006.

\subsection{Water Volume Changes $\left(d V_{\text {lake }} / d t\right)$ and Water Surface Area $\left(A_{\text {lake }}\right)$}

The monthly average water levels for Lake Tana since 1992 can be obtained from Hydroweb at http:/ / www.legos.obs-mip.fr/soa/hydrologie/hydroweb/. Hydroweb provides time-series of water levels of large rivers, about 170 lakes/reservoirs, and wetlands around the world using the merged T/P, Jason-1, Jason-2, ENVISAT, and GFO data. The processing procedures of Hydroweb are described in [58]. Our previous study [19] showed that the monthly water levels from Hydroweb agreed very well with measured water levels with an $R^{2}$ value of 0.99 and RMSE value of $13 \mathrm{~cm}$ for Lake Tana. In [19], the specific Level-Area-Volume relationships for Lake Tana have also been generated and validated using the Hydroweb water levels and Landsat imagery data. Then, for a certain Hydroweb water level, the corresponding surface area and water volume can be estimated using the Level-Area-Volume relationships. In this study, the monthly average water level from Hydroweb was assumed to represent the water level on the 15th day of each month, the water levels 
for the first day of each month were then interpolated linearly, and the corresponding surface area and water volume were further estimated using the predefined functional relationships. The change in water volume for a certain month was finally computed as the difference in the estimated water volume between the first day of the following month and current month.

\subsection{Groundwater Inflow $\left(G_{i}\right)$ and Outflow $\left(G_{0}\right)$}

Previous studies on Lake Tana showed that the groundwater contribution can be considered negligible $[59,60]$. Ref. [61] mentioned that the groundwater inflow constitutes less than $7 \%$ of the total inflow into the Lake Tana. By using an isotope hydrological approach, [32] further concluded that there was no groundwater outflow from Lake Tana, and the low groundwater inflow to the lake was presumably reduced by the thick stiff clay at the bottom of the lake. Without relevant data, the groundwater flows in the Lake Tana region are often neglected for Lake Tana [33,34]. Similarly, groundwater inflow and outflow were set to zero in this study.

\subsection{Surface Outflow from Lake $\left(Q_{o}\right)$}

Monthly outflow from Lake Tana measured at the Abay station (Figure 1) for the year 2006 were obtained from MoWR. Ref. [62] plotted the measured lake level and outflow of Lake Tana during 1976-2006, and mentioned that "after the operation of the weir in 2002, the outflow trend shows an erratic pattern since the water is diverted to the hydropower before reaching the outflow gauging station". This statement suggests the measured outflow data from the gauging station can underestimate the total outflow from Lake Tana. Ref. [63] also pointed out that there were no means available to assess the quality of measured data on the outflow from Lake Tana. Therefore, the measured outflow data may contain a certain amount of uncertainty, although such data are the best available ones. In this study, we independently estimated the outflow as the residual of the water balance. The difference between our estimated outflow and the measured outflow can be attributed to the unaccounted other outflow in the measured data, as well as the errors in the estimated outflow.

\section{Results}

\subsection{Water Balance over the Land Area of Lake Tana Basin}

We first estimated runoff as the residual of the water balance (Equation (2)) for the two gauged Gilgel Abay and Gumara catchments. The estimated runoff values were evaluated against the measured data. Table 1 summarizes the annual values of the water balance components for these two gauged catchments. The estimated annual runoff values were $1464 \mathrm{~mm} / \mathrm{yr}$ and $916 \mathrm{~mm} / \mathrm{yr}$ for Gilgel Abay and Gumara, respectively, being a substantial layer of water and among the highest in the Nile basin. They were very close to the measured runoff data, with differences of only $4 \mathrm{~mm} / \mathrm{yr}$ ( $0.27 \%$ error) and $35 \mathrm{~mm} / \mathrm{yr}$ ( $4 \%$ error), respectively. This good agreement provides confidence in the estimation of annual runoff from ungauged catchments in Africa and the magnitude of the deep percolation flux.

Table 1. The annual water balance components averaged over two gauged catchments (Gilgel Abay and Gumara) and the entire land areas of Lake Tana Basin.

\begin{tabular}{cccc}
\hline Water Balance Component & Gilgel Abay & Gumara & Whole LAND area \\
\hline Area $\left(\mathrm{km}^{2}\right)$ & 1656 & 1279 & 12050 \\
Precipitation $(\mathrm{mm})$ & 2180 & 1638 & 1637 \\
Evapotranspiration $(\mathrm{mm})$ & 546 & 573 & 651 \\
Soil moisture storage changes $(\mathrm{mm})$ & +116 & +74 & +97 \\
Deep percolation $(\mathrm{mm})$ & 54 & 74 & 326 \\
Estimated Runoff $(\mathrm{mm})$ & 1464 & 916 & 564 \\
Measured Runoff $(\mathrm{mm})$ & 1468 & 951 & Nonexistent \\
\hline
\end{tabular}


Figure 2 compares the monthly estimated runoff and measurements for the two catchments. For both catchments, there were large differences in the timing and magnitude between the estimated and measured runoff. The estimated runoff peaked in July, which is in the phase of the pattern of precipitation, and the correlation coefficient between estimated runoff and precipitation was 0.96 and 0.88 for Gilgel Abay and Gumara, respectively. However, the measured runoff peaked a month later in August due to the delay effects of infiltration, recharge, and baseflow, etc. For Gilgel Abay, the difference between estimated monthly runoff and measured runoff ranged from $3.8 \%$ (in May) to $376 \%$ (in April) of corresponding measured runoff, with the average absolute percentage of $85 \%$. For Gumara, the difference between estimated monthly runoff and measured runoff ranged from $6.3 \%$ (in June) to $445 \%$ (in May) of corresponding measured runoff, with the average absolute percentage of $164 \%$. Therefore, estimation of monthly runoff based on the residual of the water balance was not feasible in our study. We attempted to find an appropriate adjustment factor to maximize the agreement between the estimated monthly outflow and the observed outflow. We tried different ways (residual correction and lag analysis) for different input variables. Residual correction was performed as follows: first we assumed that all the discrepancies between estimated and measured runoff were contributed by one input variable (e.g., the total water storage changes). Then, we adjusted the input variable to enable the estimated runoff to match the measured runoff exactly. Then the original and adjusted values of the input variable were compared to check whether appropriate calibration factors could be determined. For the lag analysis, we tried to add different time lag values in months for estimating runoff. Unfortunately, the attempts at adjustment were not successful; we could not find a reasonable solution to extrapolate the adjustments (based on two subbasins, Gilgel Abay and Gumara, where measured outflow are available) to other ungauged basins for the estimation of runoff from the entire land area.
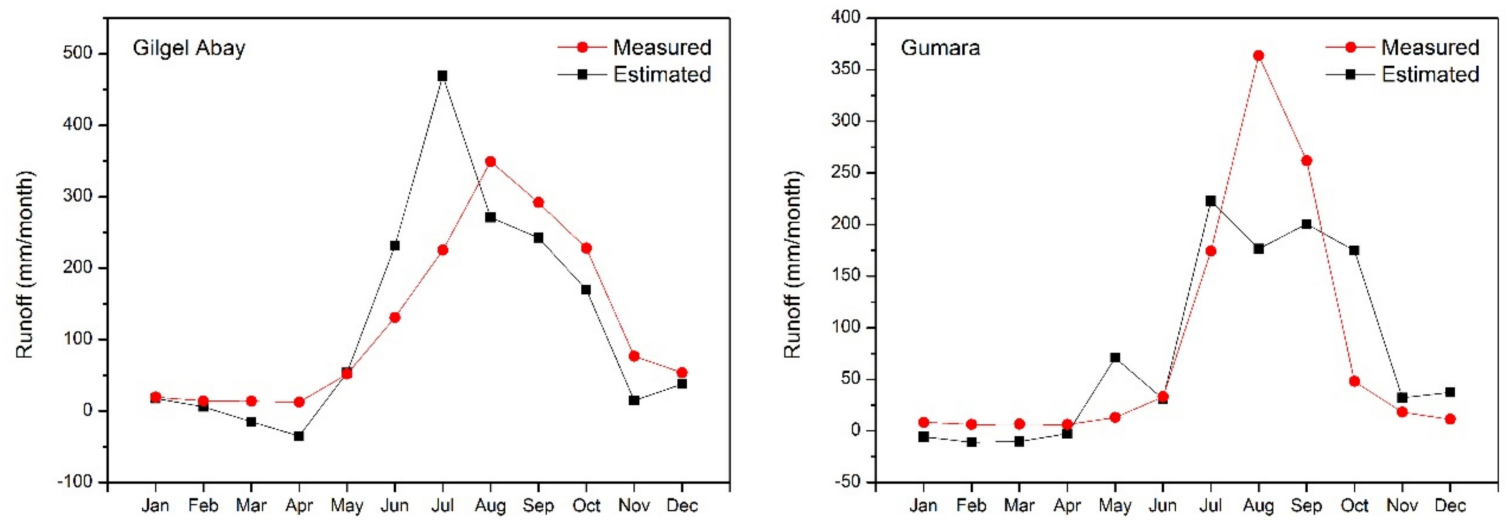

Figure 2. Monthly estimated and measured runoff over two gauged catchments Gilgel Abay and Gumara.

The annual water balance components for the whole land area surrounding Lake Tana Basin for the year 2006 are presented in Table 1. Note that the lake surface area is dynamic and varies with water level. Hence, the land area becomes a variable of the equation. The average land area is $12,050 \mathrm{~km}^{2}$, as shown in Table 1 . The total annual precipitation is $1637 \mathrm{~mm} / \mathrm{yr}$. For the year 2006, the total evapotranspiration rate over land was $651 \mathrm{~mm} / \mathrm{yr}$. Hence the rainfall surplus was $970 \mathrm{~mm} / \mathrm{yr}$, being a rather high number. The positive soil moisture change was $97 \mathrm{~mm} / \mathrm{yr}$ due to incremental water in the root zone. After the deep percolation correction of $326 \mathrm{~mm} / \mathrm{yr}$, the total surface runoff from the surrounding catchments into the lake was estimated to be $564 \mathrm{~mm} / \mathrm{yr}$.

Figure 3 shows the time-series of monthly precipitation, actual evapotranspiration, soil moisture storage changes, deep percolation, and derived runoff averaged over the whole land area of Lake Tana Basin. After knowing that monthly runoff estimates from the Gilgel Abay and Gumara catchments (Figure 2) are poor due to poor values of total water storage changes, we did not expect the monthly estimated runoff for the entire land area to be satisfactory. As shown in Figure 3, in the first 
four months, the estimated runoff values were small negative values ranging from $-2 \mathrm{~mm} / \mathrm{month}$ in January to $-26 \mathrm{~mm} / \mathrm{month}$ in April. The outflow towards the lake is virtually zero during this period, but withdrawals for irrigation, domestic, and industrial water purposes take place. Hence a net transfer of water resources from the lake area towards the surrounding catchments takes place. Similar to the two gauged catchments, the estimated runoff peaked in July when the maximum precipitation occurred. The runoff should peak in August according to the long-term trend analysis by [61]. In their study, the long-term average monthly lake inflow values were very close to zero for dry months January-May, but they do not report on withdrawing irrigation water to the fringe area with crop surfaces. The monthly estimated runoff values in the unit of depth $(\mathrm{mm} / \mathrm{month})$ were multiplied by the corresponding land areas to convert them to the volumetric values (MCM/month; MCM refers to the unit of million cubic meter). The volumetric runoff values were then used as the total lake inflow for analysis of the water balance of Lake Tana.

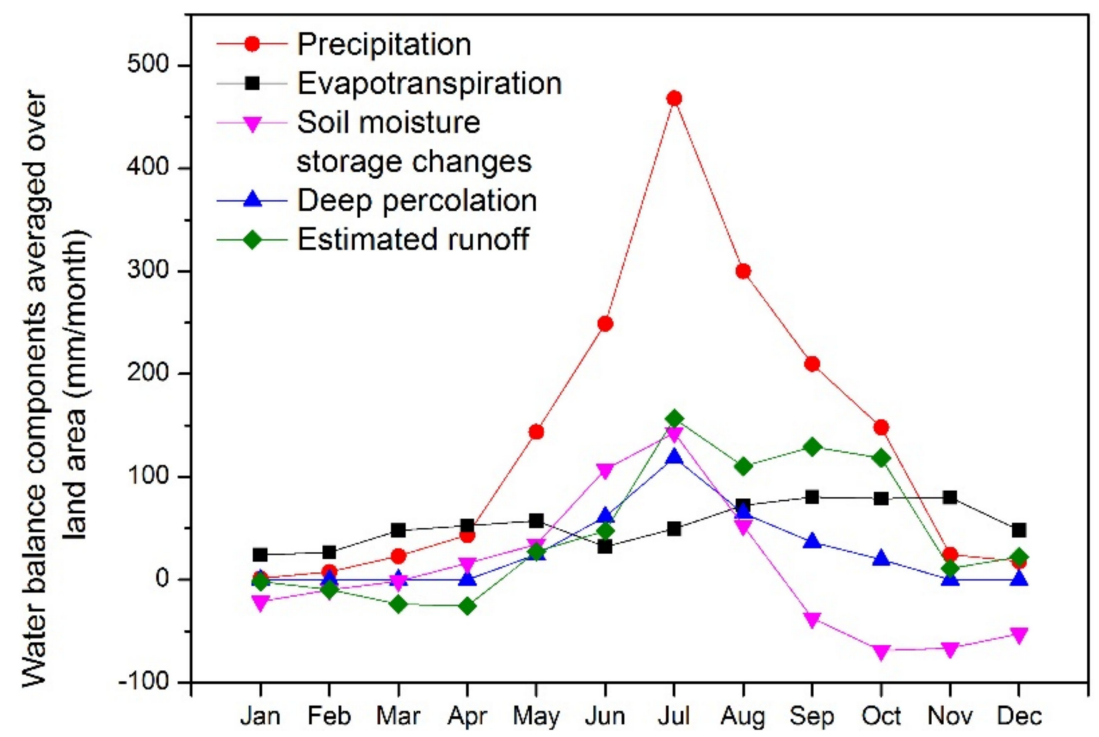

Figure 3. Monthly values of water balance components averaged over the whole land area of Lake Tana Basin.

\subsection{Water Balance of Lake Tana}

The monthly water balance components of Lake Tana for the year 2006 are summarized in Table 2. The measured outflow data from a station are also included. The large discrepancy between them can be observed, as reflected in the "Difference" column, and the difference between them ranged from $-567 \mathrm{~mm} / \mathrm{month}$ in August to $314 \mathrm{~mm} /$ month in October. Figure 4 shows cumulative monthly estimated and measured outflow. Although the possible errors are other outflows such as (i) irrigation, (ii) domestic water, (iii) industrial water, and (iv) deep percolation, the uncertainty in monthly total water storage changes causing the poor estimates of lake inflow was most likely to be the major reason for the large discrepancy between estimated and measured outflow. 
Table 2. Monthly water balance components of Lake Tana.

\begin{tabular}{|c|c|c|c|c|c|c|c|}
\hline Months & $\begin{array}{c}\text { Lake } \\
\text { INFLOW } \\
(\mathrm{mm})\end{array}$ & $\begin{array}{c}\text { Lake } \\
\text { Precipitation } \\
(\mathrm{mm})\end{array}$ & $\begin{array}{c}\text { Lake } \\
\text { Evaporation } \\
(\mathrm{mm})\end{array}$ & $\begin{array}{c}\text { Change in } \\
\text { Storage }(\mathrm{mm})\end{array}$ & $\begin{array}{c}\text { Estimated } \\
\text { Total Outflow } \\
(\mathrm{mm})\end{array}$ & $\begin{array}{c}\text { Measured } \\
\text { Outflow } \\
(\mathrm{mm})\end{array}$ & $\begin{array}{l}\text { Difference } \\
\quad(\mathrm{mm})\end{array}$ \\
\hline January & -7 & 12 & 141 & -224 & 88 & 73 & 15 \\
\hline February & -36 & 50 & 121 & -252 & 144 & 62 & 82 \\
\hline March & -94 & 45 & 133 & -252 & 70 & 73 & -2 \\
\hline April & -102 & 83 & 127 & -272 & 126 & 77 & 49 \\
\hline May & 110 & 127 & 139 & -128 & 226 & 81 & 145 \\
\hline June & 192 & 246 & 138 & 64 & 236 & 81 & 154 \\
\hline July & 630 & 389 & 155 & 570 & 293 & 87 & 206 \\
\hline August & 435 & 286 & 160 & 990 & -429 & 137 & -567 \\
\hline September & 505 & 182 & 146 & 429 & 112 & 405 & -292 \\
\hline October & 462 & 120 & 145 & -106 & 544 & 231 & 314 \\
\hline November & 43 & 74 & 138 & -157 & 136 & 141 & -5 \\
\hline December & 88 & 38 & 144 & -229 & 211 & 120 & 91 \\
\hline
\end{tabular}

Annual water balance components of Lake Tana are summarized in Table 3. The annual total lake inflow was $6788 \mathrm{MCM} / \mathrm{yr}$. Note that the lake surface area varied for each month. The average surface area of Lake Tana for the study period was $3044 \mathrm{~km}^{2}$. The lake surface area was used to convert water volumes to the unit of depth. The annual total lake inflow was $2226 \mathrm{~mm} / \mathrm{yr}$. There was an increase of $1320 \mathrm{MCM} / \mathrm{yr}$ in the lake water storage due to the relatively large inflow by abundant rainfall. The water level of Lake Tana increased by $432 \mathrm{~mm} / \mathrm{yr}$. The estimated total outflow from the water body was $1757 \mathrm{~mm} / \mathrm{yr}$, assuming that no other water outlets exist in the basin. The measured outflow at a station was $1566 \mathrm{~mm} / \mathrm{yr}$. The difference between the estimated total outflow and measured outflow was $191 \mathrm{~mm} / \mathrm{yr}$, accounting for $12 \%$ of measured lake outflow. Considering that the accuracy of discharge measurements is generally within $20 \%$, the estimated annual outflow can be considered to be quite satisfactory.

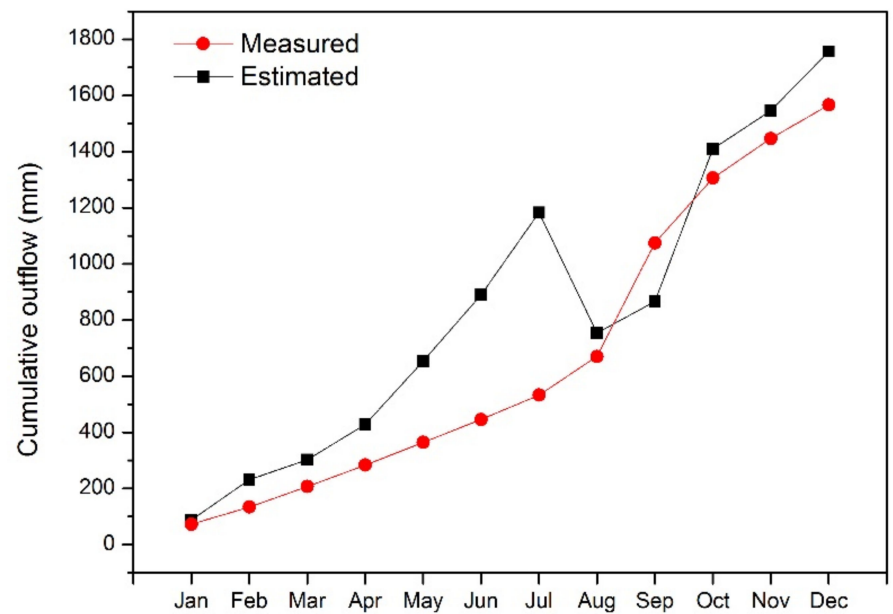

Figure 4. Cumulative values of monthly estimated total outflow and measured outflow from Lake Tana.

Table 3. Annual water balance components of Lake Tana.

\begin{tabular}{ccc}
\hline Water Balance Components & $\begin{array}{c}\text { Depth } \\
\text { (mm/yr) }\end{array}$ & $\begin{array}{c}\text { Volume } \\
\text { (MCM/yr) }\end{array}$ \\
\hline Inflow & 2226 & 6788 \\
Precipitation & 1652 & 5014 \\
Evaporation & 1688 & 5138 \\
Change in storage & +432 & +1320 \\
Estimated total outflow & 1757 & 5343 \\
Measured outflow & 1566 & 4789 \\
Difference & 191 & 554 \\
\hline
\end{tabular}




\section{Discussion}

\subsection{Comparison with Previous Water Balance Studies in Lake Tana}

Since more than $50 \%$ of areas of Lake Tana Basin are ungauged, there is thus no real value for the total lake inflow to Lake Tana. It is interesting and relevant to compare our estimated lake inflow presented in this study with values of previous studies (but considered for different years and periods). Ref. [33] estimated the long-term average annual total lake inflow to be $2160 \mathrm{~mm} / \mathrm{yr}$ (6699 MCM/yr) for Lake Tana during the period 1995-2001. The corresponding precipitation over the lake was $1220 \mathrm{~mm} / \mathrm{yr}$, which was estimated by the spatial interpolation of the five rain gauges around the lake. Ref. [34] estimated the average annual total lake inflow as $1781 \mathrm{~mm} / \mathrm{yr}(5426 \mathrm{MCM} / \mathrm{yr})$ for the period 1994-2003, and the precipitation was estimated as $1347 \mathrm{~mm} / \mathrm{yr}$. These two studies used similar methods for the estimation of total lake inflow from the land basins. They firstly used measured runoff from several gauged basins (accounting for less than $40 \%$ of the total Lake Tana Basin) to calibrate the HBV rainfall-runoff model, and the calibrated parameters were then transferred through generalization procedures to the ungauged basin for runoff simulation.

Because the reported values from the two studies are the long-term mean values, it is not reasonable to make a direct comparison with our estimated value for a specific wet year. Instead, a relative comparison was made as follows. The estimated precipitation of $1652 \mathrm{~mm} / \mathrm{yr}$ over Lake Tana in 2006 was higher than the long-term mean precipitation reported by the above two previous studies. However, both studies did not report the corresponding precipitation over the land areas. As shown in Tables 1 and 2, the precipitation averaged over the land area was very close to that over the lake, and thus we may use precipitation over the lake area to represent precipitation over the land area as well. As a result, a higher lake inflow in 2006 was as expected. If we further assume that there is a simple linear relationship between precipitation and lake inflow, then we may infer the possible lake inflow for the specific year using the long-term average precipitation and lake inflow and the real precipitation for a certain year. For example, if we used the results from [33], because the ratio of the estimated precipitation in 2006 to the long-term mean average precipitation (1652/1220) was 1.35, the possible lake inflow for the year 2006 can thus be inferred by multiplying the long-term average lake inflow of $2160 \mathrm{~mm} / \mathrm{yr}$ with the ratio of 1.35 . The inferred lake inflow would be $2925 \mathrm{~mm} / \mathrm{yr}$, which is considerably higher than our estimate value by $699 \mathrm{~mm} / \mathrm{yr}$. A similar procedure was conducted using the long-term average lake inflow reported by [34], and the inferred lake inflow was then $2183 \mathrm{~mm} / \mathrm{yr}$, which is very close to our estimated value (2226 mm/yr).

The deep percolation process in Lake Tana Basin is rather a debate in the literature; existing studies only based on hydrological modelling techniques found that a considerable amount of water has to be allocated to deep percolation which does not contribute to the lake inflow, but the authors seems to be not very confident about this because of uncertainties from model calibration and used parameter regionalization $[47,48]$. The value of $326 \mathrm{~mm} / \mathrm{yr}$ for the annual deep percolation averaged over the whole land area of Lake Tana Basin appears to be large. The use of this value, however, resulted in a reasonable runoff (also lake inflow) in this study. In other words, if we calculate the deep percolation (instead of lake outflow in this study) as the residual of the water balance, we would obtain a similar large value for the annual deep percolation. Therefore, this study provides further support for the significant deep percolation processes in Lake Tana Basin. Other studies also support significant deep percolation processes in the Blue Nile Basin [15,30,46-48]. More efforts should be made in future studies to improve our understanding of the deep percolation processes in Lake Tana Basin and entire Blue Nile Basin.

\subsection{Discussion of Discrepancies at Monthly Results}

As shown in Table 1 and Figure 2, the estimated runoff for two gauged subbasins agreed well with measurements at the annual scale, but not at the monthly scale. Since the runoff was estimated as the residual of the land-based water balance (Equation (2)), any error in other water 
balance components would influence the estimated runoff. The precipitation component was already calibrated with available rain gauge stations, and possible error in evapotranspiration could be also limited, as the review by [64] showed that satellite-based methods were able to produce reliable actual evapotranspiration estimates with a mean absolute error of $5.4 \%$. Therefore, the large discrepancy between estimated and measured monthly runoff could be most likely due to the poor quantification of monthly soil moisture storage changes and the estimation of monthly deep percolation. It should be noted that the spatial resolution of Noah soil moisture data $\left(0.25^{\circ}\right)$ is not consistent with precipitation and actual evapotranspiration $(1 \mathrm{~km})$ used in this study. The GLDAS is intended for global scale climate analysis and these forcing data thus relate to a coarser spatial resolution. For example, the well-known most critical input precipitation data to the Noah model were CAMP precipitation at a $2.5^{\circ}$ spatial resolution followed by spatial and temporal downscaling procedures [65]. The precipitation used may be inappropriate to capture the rainfall of river basins with a smaller size. The soil water holding capacity of layered soils is also known to be a very sensitive calibration parameter. The values for several parameters in the default global model may be inappropriate to represent the local situation of the poorly gauged Lake Tana Basin. In addition, notable errors in the Noah modelled outputs have been reported for several river basins $[66,67]$. The above issues reduced our confidence in the accuracy of the Noah soil moisture data for Lake Tana Basin. For deep percolation, the partition of annual deep percolation obtained from long-term average values reported in the literature into monthly values may also be inappropriate and introduce errors. More studies should be conducted to improve the qualification of soil moisture storage changes and deep percolation.

The negative values of estimated runoff in the Lake Tana Basin in spring as shown in Figure 3 could also be partially caused by irrigation. Irrigation in spring can result in larger ET values than natural ET, which could result in the negative runoff. For irrigation, Ref. [60] mentioned that a total area of $250-300 \mathrm{~km}^{2}$ was cultivated around Lake Tana. We did a rather simple analysis to confirm the possibility of irrigation in Lake Tana Basin during dry months. We checked the $1 \mathrm{~km}$ spatial resolution NDVI maps from SPOT satellite data during the dry months January-April when precipitation was less than $50 \mathrm{~mm} / \mathrm{month}$ (Figure 2). Some areas around the Lake Tana (southwestern, eastern and northern parts) and some areas scattered in the south part of the Lake Tana Basin showed consistently higher NDVI values than surrounding areas. Such pixels were overlaid on Google Earth and further confirmed that the corresponding areas with higher NDVI values were croplands instead of forest. The number of irrigated areas is expected to grow because large irrigation development projects have been proposed and parts of them are under construction in the Lake Tana Basin [60]. However, the influence of irrigation on the water balance of Lake Tana itself can be very small on the annual scale. Ref. [68] estimated the annual water abstraction by irrigation to be $133 \mathrm{MCM} / \mathrm{yr}$, which is around $43 \mathrm{~mm} / \mathrm{yr}$ depth over the Lake Tana for the years 2012 and 2013. The value $43 \mathrm{~mm} / \mathrm{yr}$ from irrigation accounts for only a very small percentage (2.7\%) of the measured lake outflow (1566 mm/yr, Table 3).

After knowing that estimates of monthly runoff from the surrounding basin (lake inflow) were not accurate, poor agreement between the estimated lake outflow and measured outflow was expected. In addition, uncertainties from all other water components, i.e., precipitation over the lake, and lake evaporation, lake volume changes, and the common neglect of groundwater, were introduced into the final estimate of lake outflow. Such uncertainties could be significantly reduced at the annual scale, resulting in acceptable estimates of annual lake outflow. Our findings were consistent with [28], which also found that the estimated annual lake outflow values were reasonable, but estimated monthly outflow values were unsatisfactory for Kaptai Reservoir and Hungry Horse Reservoir. Ref. [29] estimated monthly lake outflow as a residual of the water balance in Lake Nasser and Roseires Reservoir in the Nile Basin. The reasonable monthly estimates of outflow were founded for Roseries Reservoir but not for Lake Nasser. However, complete data on lake inflow is not even existent for poorly gauged basins, and thus methods with an intense demand for measured data could not be applied for certain areas including Lake Tana in this study. When taking together findings from the aforementioned three most relevant studies $[2,28,29]$ and our current study, we could conclude that 
estimating the monthly outflow from lakes and reservoirs as a residual of the water balance suffers from large uncertainties, which highlights that more efforts are needed to improve the qualification of each individual water balance component either from in-situ measurements, satellite remote sensing, or ideally a combination of both. In addition, human activity such as irrigation can also affect the water balance of lakes and the river basins, which should also be taken into account in future studies.

\subsection{Limitations and Recommendations for Future Study}

As mentioned above, the runoff (lake inflow) and lake outflow were estimated as the residual of the water balance for the land and lake, respectively. Any error or uncertainty in the other water balance components (used as input) would influence the estimated runoff and further the lake outflow. Several studies discussed how to quantify uncertainties in water balance components [69-72]. However, more additional data and information are needed, together with many assumptions that have to be made in such uncertainty analyses. The lack of such data has consequently led to the fact that many studies cannot perform a rigorous uncertainty analysis, as also mentioned by [72]. Unfortunately, in the current study, we did not have enough data on the uncertainty associated with each water balance component to perform an appropriate uncertainty analysis and propagation of uncertainty into the resulting runoff and lake outflow. We acknowledge these as limitations of our current study and highlight the need for uncertainty analysis to be conducted for similar future studies when and where necessary data are available. Actually, we tried our best to obtain the quantitative information on the uncertainty for each variable, but such information is often not available from the data provider, such as GLDAS, ETLook, and SSEBop used in this study. This is somehow understandable, because the satellite-based products are also estimates using a certain number of input variables to certain retrieval algorithms or models, and it is difficult to quantify the uncertainty associated with the input variables and consequently to uncertainty associated with the resulting output. In this regard, using multiple data sources (satellite products in this case) could be a way to obtain hints on uncertainty for a certain input variable. Ideally, in-situ measurements can be used to quantify the uncertainty associated with each variable, but the studied Lake Tana is a poorly gauged one and we cannot obtain necessary data in this study. This indeed highlights the need for obtaining more measurements through the innovation monitoring techniques, as stressed in the new MOXXI working group mentioned in the Section 1. Therefore, we call for more attention to be placed on the appropriate quantification of uncertainty associated with each water balance component in future study.

We would like to discuss the possible uncertainties or error ranges for some water balance components based on the literature review and our previous studies. Such discussion was focused on an annual timescale only because uncertainties for monthly components were not well known and could show very large variations among seasons [69-71]. To have a rough idea of the influence of uncertainty/error ranges for a given component on the results, we performed a simple sensitivity analysis. For annual precipitation over the land $P_{\text {land, }}$ Ref. [36] showed that the integrated precipitation was within $5 \%$ of measurements from a limited number of available rain gauge stations in the same Lake Tana Basin. By only adding +/ -5\% of current annual precipitation over the land (1637 mm/yr) as errors would lead to $+/-14 \%$ change in estimated runoff and further $+/-18 \%$ change in estimated lake outflow. For actual evapotranspiration ( $\left.\mathrm{ET}_{\mathrm{land}}\right)$, using the mean error of $+/-5.4 \%$ reported by [64], would translate to $-/+6 \%$ change in estimated runoff and $-/+8 \%$ change in estimated lake outflow. For lake evaporation, Ref. [37] showed that the annual estimate could be within 15\% of measured evaporation from the average results of five other different lakes, which would result in comparable change (14\%) in the estimated lake outflow. The error in the estimated lake water volume was around $10 \%$ of measurements based on validation in Lake Tana for a long time period of 1992-2006 [19]. Using $10 \%$ change in the lake water volume change $\left(\mathrm{dV}_{\text {lake }} / \mathrm{dt}\right)$ would lead to $2 \%$ change in the estimated runoff. The uncertainties for the component, changes in the water storage over land area $\left(\mathrm{dS}_{\text {land }} / \mathrm{dt}\right)$ including soil moisture storage change and deep percolation, were not well known. In this study, we used an average value of $325.5 \mathrm{~mm} / \mathrm{yr}$ for annual deep percolation. If we used either of 
the reported values of $251 \mathrm{~mm} / \mathrm{yr}$ and $400 \mathrm{~mm} / \mathrm{yr}$, accounting for changes of $-/+23 \%$ in the deep percolation, then the estimated annual runoff from the whole land area estimate would have $+/-13 \%$ change of current estimated runoff (564 mm/yr). Further, this change would lead to around $+/-17 \%$ change of the current estimated lake outflow $(1757 \mathrm{~mm} / \mathrm{yr})$.

The precipitation over the lake $\left(\mathrm{P}_{\text {lake }}\right)$ is another water balance component for which the uncertainty is not well known, mainly due to the lack of measurements over the water surface for evaluation. Previous studies reported that satellite precipitation estimates could overestimate precipitation over inland waterbodies due to deficiencies in emissivity characterization used in the passive microwave-based rainfall retrieval algorithms [73,74]. However, the opposite finding was reported by [75], who found underestimation by satellite precipitation. These contrasting findings indeed highlight the need for more studies on this topic in future studies. Again, the in-situ measurements over lakes are necessary for a comprehensive and representative evaluation of satellite precipitation over inland waterbodies, which would provide valuable information on the uncertainties.

We would like to draw attention to the influence of hydropower plants on the water balance of lakes and reservoirs. For Lake Tana, the Tana Beles Hydropower Scheme was made operational in May 2010, and thus since then, Lake Tana has two outlets for the lake outflow [68]. The outflow from this hydropower outlet had no influence in our current study because of the focused year, but the amount of hydropower water consumption should be taken into account for analysis of the water balance of Lake Tana from 2010 in future studies.

\section{Conclusions}

In this study, the water balance of Lake Tana and its surrounding basin (a poorly gauged study area) was assessed using satellite remote sensing and routine weather measurements together with public domain data. In particular, we investigated whether the surface outflow from Lake Tana can be estimated as a residual of the water balance. The novel satellite remote sensing techniques and modelling algorithms studies on precipitation, lake water volume changes, heat storage changes, and lake evaporation have been integrated to this case study. To our best knowledge, this study explored satellite remote sensing to a larger extent in quantifying the water balance and estimating lake outflow in poorly gauged lakes/reservoirs, and it is the first such study applied to Lake Tana. The measured outflow was available for two gauged catchments and Lake Tana. The inflow into Lake Tana was estimated as the surface runoff from all catchments draining into the lake area. It can be concluded that both estimates of annual runoff from ungauged catchments and annual lake outflow were satisfactory. The estimated annual outflow from Lake Tana was also close to measured outflow, with a difference of $12 \%$. However, monthly runoff from catchments and monthly lake outflow were not satisfactory, with large errors. Our current study together with existing relevant studies showed that estimating the monthly outflow from lakes and reservoirs as a residual of the water balance suffers from large uncertainties. This calls for more efforts in improving the qualification of each individual water balance component either from in-situ measurements, satellite remote sensing, or ideally a combination of both. In addition, our study provides further support for the significant deep percolation processes in Lake Tana Basin. More attention should be paid to improve our understanding of the deep percolation processes in Lake Tana Basin and entire Blue Nile Basin. Our current study investigated only one year due to the limited availability of all necessary in-situ measured data. We acknowledge and stress this as a limitation of our current study. More studies with reliable measurements need to be investigated to better understand the water balance of Lake Tana and its surrounding catchments. Furthermore, it is acknowledged that this study made several assumptions and simplifications that warrant future detailed studies as more data are available. The validity of the measurements in the upper Blue Nile Basin was somewhat questioned by [31]. They pointed out the need for additional measurements and better methods to confirm the quality and validity of measurements. The good news is that new research programs in the Blue Nile have been initiated for this purpose. In addition, the aforementioned MOXXI working group is also expected to improve the data monitoring and data 
sharing situation in currently poorly or ungauged basins. Hopefully, more reliable measurements (e.g., outflow) in Lake Tana can be made available to gain more confidence in evaluating new methods. This study demonstrates that the availability of precipitation, land evapotranspiration, lake water volume changes, lake heat storage changes, and lake evaporation information from open-access earth observation datasets and routine weather measurements, provides more insights in the hydrological processes. This study is expected to shed light on many other similar lakes, particularly the poorly gauged ones. We would like to call for more attention on the appropriate quantification of uncertainty for each water balance (in particular the changes in the water storage over land area and precipitation over the lake) and rigorous uncertainty analysis for lake water balance in future study.

Author Contributions: Z.D. conceived this study, did data processing and analysis, and wrote the original version of manuscript. H.G. and C.Q.K. provided constructive comments through extensive discussion and improved the manuscript. All the co-authors assisted in the finalization of the manuscript.

Funding: This study was supported by the National Key R\&D Program of China (2017YFE0100700), and financially supported by the Key Laboratory for Mountain Hazards and Earth Surface Process, Institute of Mountain Hazards and Environment, Chinese Academy of Sciences (KLMHESP-17-02). This work was supported by the German Research Foundation (DFG) and the Technical University of Munich (TUM) in the framework of the Open Access Publishing Program.

Acknowledgments: We acknowledge the Ethiopian National Meteorological Agency (ENMA) and Ministry of Water Resources (MoWR), Ethiopia for providing relevant measured data. Thanks also go to all providers for making relevant satellite data or simulation outputs available to the public. We thank three anonymous reviewers for providing constructive comments, which greatly improved this manuscript.

Conflicts of Interest: The authors declare no conflict of interest.

\section{References}

1. Medina, C.E.; Gomez-Enri, J.; Alonso, J.J.; Villares, P. Water level fluctuations derived from ENVISAT radar altimeter (RA-2) and in-situ measurements in a subtropical waterbody: Lake Izabal (Guatemala). Remote Sens. Environ. 2008, 112, 3604-3617. [CrossRef]

2. Swenson, S.; Wahr, J. Monitoring the water balance of Lake Victoria, East Africa, from space. J. Hydrol. 2009, 370, 163-176. [CrossRef]

3. Tauro, F.; Selker, J.; van de Giesen, N.; Abrate, T.; Uijlenhoet, R.; Porfiri, M.; Manfreda, S.; Caylor, K.; Moramarco, T.; Benveniste, J. Measurements and observations in the XXI century (MOXXI): Innovation and multi-disciplinarity to sense the hydrological cycle. Hydrol. Sci. J. 2018, 63, 169-196. [CrossRef]

4. Gao, H.; Hrachowitz, M.; Fenicia, F.; Gharari, S.; Savenije, H. Testing the realism of a topography-driven model (FLEX-topo) in the nested catchments of the Upper Heihe, China. Hydrol. Earth Syst. Sci. 2014, 18, 1895-1915. [CrossRef]

5. Gao, H.; Cai, H.; Duan, Z. Understand the impacts of landscape features on the shape of storage capacity curve and its influence on flood. Hydrol. Res. 2017, 49. [CrossRef]

6. Hrachowitz, M.; Savenije, H.; Blöschl, G.; McDonnell, J.; Sivapalan, M.; Pomeroy, J.; Arheimer, B.; Blume, T.; Clark, M.; Ehret, U. A decade of predictions in ungauged basins (pub)—A review. Hydrol. Sci. J. 2013, 58, 1198-1255. [CrossRef]

7. Blume, T.; van Meerveld, I.; Weiler, M. The role of experimental work in hydrological sciences-Insights from a community survey. Hydrol. Sci. J. 2017, 62, 334-337. [CrossRef]

8. Duan, Z.; Liu, J.; Tuo, Y.; Chiogna, G.; Disse, M. Evaluation of eight high spatial resolution gridded precipitation products in Adige Basin (Italy) at multiple temporal and spatial scales. Sci. Total Environ. 2016, 573, 1536-1553. [CrossRef] [PubMed]

9. Kidd, C.; Huffman, G. Global precipitation measurement. Meteorol. Appl. 2011, 18, 334-353. [CrossRef]

10. Bastiaanssen, W.G.M.; Cheema, M.J.M.; Immerzeel, W.W.; Miltenburg, I.J.; Pelgrum, H. Surface energy balance and actual evapotranspiration of the transboundary Indus Basin estimated from satellite measurements and the ETLook model. Water Resour. Res. 2012, 48. [CrossRef]

11. Long, D.; Singh, V.P. A two-source trapezoid model for evapotranspiration (TTME) from satellite imagery. Remote Sens. Environ. 2012, 121, 370-388. [CrossRef] 
12. Mu, Q.; Zhao, M.; Running, S.W. Improvements to a MODIS global terrestrial evapotranspiration algorithm. Remote Sens. Environ. 2011, 115, 1781-1800. [CrossRef]

13. Senay, G.B.; Bohms, S.; Singh, R.K.; Gowda, P.H.; Velpuri, N.M.; Alemu, H.; Verdin, J.P. Operational evapotranspiration mapping using remote sensing and weather datasets: A new parameterization for the sseb approach. JAWRA J. Am. Water Resour. Assoc. 2013, 49, 577-591. [CrossRef]

14. Long, D.; Longuevergne, L.; Scanlon, B.R. Global analysis of approaches for deriving total water storage changes from grace satellites. Water Resour. Res. 2015, 51, 2574-2594. [CrossRef]

15. Bastiaanssen, W.G.M.; Karimi, P.; Rebelo, L.-M.; Duan, Z.; Senay, G.; Muttuwatte, L.; Smakhtin, V. Earth observation based assessment of the water production and water consumption of Nile Basin agro-ecosystems. Remote Sens. 2014, 6, 10306-10334. [CrossRef]

16. Calmant, S.; Seyler, F.; Cretaux, J.F. Monitoring continental surface waters by satellite altimetry. Surv. Geophys. 2008, 29, 247-269. [CrossRef]

17. Zhang, G.; Xie, H.; Kang, S.; Yi, D.; Ackley, S.F. Monitoring lake level changes on the Tibetan Plateau using ICESat altimetry data (2003-2009). Remote Sens. Environ. 2011, 115, 1733-1742. [CrossRef]

18. Baup, F.; Frappart, F.; Maubant, J. Combining high-resolution satellite images and altimetry to estimate the volume of small lakes. Hydrol. Earth Syst. Sci. 2014, 18, 2007-2020. [CrossRef]

19. Duan, Z.; Bastiaanssen, W.G.M. Estimating water volume variations in lakes and reservoirs from four operational satellite altimetry databases and satellite imagery data. Remote Sens. Environ. 2013, 134, 403-416. [CrossRef]

20. Frappart, F.; Papa, F.; Güntner, A.; Susanna, W.; Ramillien, G.; Prigent, C.; Rossow, W.B.; Bonnet, M.-P. Interannual variations of the terrestrial water storage in the Lower $\mathrm{Ob}^{\prime}$ Basin from a multisatellite approach. Hydrol. Earth Syst. Sci. Discuss. 2010, 14, 2443-2453. [CrossRef]

21. Singh, A.; Behrangi, A.; Fisher, J.B.; Reager, J.T. On the Desiccation of the South Aral Sea Observed from Spaceborne Missions. Remote Sens. 2018, 10, 793. [CrossRef]

22. Singh, A.; Seitz, F.; Eicker, A.; Güntner, A. Water Budget Analysis within the Surrounding of Prominent Lakes and Reservoirs from Multi-Sensor Earth Observation Data and Hydrological Models: Case Studies of the Aral Sea and Lake Mead. Remote Sens. 2016, 8, 953. [CrossRef]

23. Singh, A.; Seitz, F.; Schwatke, C. Inter-annual water storage changes in the Aral Sea from multi-mission satellite altimetry, optical remote sensing, and GRACE satellite gravimetry. Remote Sens. Environ. 2012, 123, 187-195. [CrossRef]

24. Song, C.; Huang, B.; Ke, L. Modeling and analysis of lake water storage changes on the Tibetan Plateau using multi-mission satellite data. Remote Sens. Environ. 2013, 135, 25-35. [CrossRef]

25. Duan, Z.; Bastiaanssen, W.G.M. A new empirical procedure for estimating intra-annual heat storage changes in lakes and reservoirs: Review and analysis of 22 lakes. Remote Sens. Environ. 2015, 156, 143-156. [CrossRef]

26. Yin, X.; Nicholson, S.E. The water balance of Lake Victoria. Hydrol. Sci. J. 1998, 43, 789-811. [CrossRef]

27. Zhang, Z.; Huang, Y.; Xu, C.-Y.; Chen, X.; Moss, E.M.; Jin, Q.; Bailey, A.M. Analysis of Poyang Lake water balance and its indication of river-lake interaction. SpringerPlus 2016, 5, 1555. [CrossRef] [PubMed]

28. Bonnema, M.; Sikder, S.; Miao, Y.; Chen, X.; Hossain, F.; Ara Pervin, I.; Mahbubur Rahman, S.; Lee, H. Understanding satellite-based monthly-to-seasonal reservoir outflow estimation as a function of hydrologic controls. Water Resour. Res. 2016, 52, 4095-4115. [CrossRef]

29. Muala, E.; Mohamed, Y.A.; Duan, Z.; van der Zaag, P. Estimation of reservoir discharges from Lake Nasser and Roseires Reservoir in the Nile Basin using satellite altimetry and imagery data. Remote Sens. 2014, 6, 7522-7545. [CrossRef]

30. Setegn, S.G.; Srinivasan, R.; Melesse, A.M.; Dargahi, B. SWAT model application and prediction uncertainty analysis in the Lake Tana Basin, Ethiopia. Hydrol. Process. 2010, 24, 357-367. [CrossRef]

31. Uhlenbrook, S.; Mohamed, Y.; Gragne, A. Analyzing catchment behavior through catchment modeling in the Gilgel Abay, upper Blue Nile River basin, Ethiopia. Hydrol. Earth Syst. Sci. 2010, 14, 2153-2165. [CrossRef]

32. Kebede, S.; Admasu, G.; Travi, Y. Estimating ungauged catchment flows from Lake Tana floodplains, Ethiopia: An isotope hydrological approach. Isot. Environ. Health stud. 2011, 47, 71-86. [CrossRef] [PubMed]

33. Wale, A.; Rientjes, T.; Gieske, A.; Getachew, H. Ungauged catchment contributions to Lake Tana's water balance. Hydrol. Process. 2009, 23, 3682-3693. [CrossRef]

34. Rientjes, T.; Perera, B.; Haile, A.; Reggiani, P.; Muthuwatta, L. Regionalisation for lake level simulationThe case of Lake Tana in the Upper Blue Nile, Ethiopia. Hydrol. Earth Syst. Sci. 2011, 15, 1167. [CrossRef] 
35. Samaniego, L.; Bárdossy, A.; Kumar, R. Streamflow prediction in ungauged catchments using copula-based dissimilarity measures. Water Resour. Res. 2010, 46. [CrossRef]

36. Duan, Z.; Bastiaanssen, W. First results from version 7 TRMM 3B43 precipitation product in combination with a new downscaling-calibration procedure. Remote Sens. Environ. 2013, 131, 1-13. [CrossRef]

37. Duan, Z.; Bastiaanssen, W.G.M. Evaluation of three energy balance-based evaporation models for estimating monthly evaporation for five lakes using derived heat storage changes from a hysteresis model. Environ. Res. Lett. 2017, 12, 024005. [CrossRef]

38. Taye, M.T.; Willems, P. Temporal variability of hydroclimatic extremes in the Blue Nile basin. Water Resour. Res. 2012, 48. [CrossRef]

39. Huffman, G.J.; Bolvin, D.T.; Nelkin, E.J.; Wolff, D.B.; Adler, R.F.; Gu, G.; Hong, Y.; Bowman, K.P.; Stocker, E.F. The TRMM multisatellite precipitation analysis (TMPA): Quasi-global, multiyear, combined-sensor precipitation estimates at fine scales. J. Hydrometeorol. 2007, 8, 38-55. [CrossRef]

40. Senay, G.B.; Asante, K.; Artan, G. Water balance dynamics in the Nile Basin. Hydrol. Process. 2009, 23, 3675-3681. [CrossRef]

41. Senay, G.B.; Velpuri, N.M.; Bohms, S.; Demissie, Y.; Gebremichael, M. Understanding the hydrologic sources and sinks in the Nile Basin using multisource climate and remote sensing data sets. Water Resour. Res. 2014, 50, 8625-8650. [CrossRef]

42. Rodell, M.; Houser, P.; Jambor, U.; Gottschalck, J.; Mitchell, K.; Meng, C.; Arsenault, K.; Cosgrove, B.; Radakovich, J.; Bosilovich, M. The global land data assimilation system. Bull. Am. Meteorol. Soc. 2004, 85, 381-394. [CrossRef]

43. Ek, M.; Mitchell, K.; Lin, Y.; Rogers, E.; Grunmann, P.; Koren, V.; Gayno, G.; Tarpley, J. Implementation of Noah land surface model advances in the National Centers for Environmental Prediction operational mesoscale Eta model. J. Geophys. Res. Atmos. 2003, 108. [CrossRef]

44. Nadew, G.A. Groundwater \& Surface Water Interaction in Lake Tana Sub-Basin Using Isotope and Geochemical Approach. Ph.D. Thesis, Addis Ababa University, Addis Ababa, Ethiopia, 2010.

45. Engida, Z.; Yilma, S.; Tuinhof, A. Groundwater Resources in Lake Tana Sub Basin and Adjacent Areas. World Bank Report; Federal Republic of Ethiopia: Adis Ababa, Ethiopia; World Bank: Washington, DC, USA, 2007.

46. Betrie, G.D.; Mohamed, Y.A.; van Griensven, A.; Srinivasan, R. Sediment management modelling in the Blue Nile Basin using SWAT model. Hydrol. Earth Syst. Sci. 2011, 15, 807. [CrossRef]

47. Gebremicael, T.; Mohamed, Y.; Betrie, G.; van der Zaag, P.; Teferi, E. Trend analysis of runoff and sediment fluxes in the Upper Blue Nile basin: A combined analysis of statistical tests, physically-based models and landuse maps. J. Hydrol. 2013, 482, 57-68. [CrossRef]

48. Griensven, A.V.; Ndomba, P.; Yalew, S.; Kilonzo, F. Critical review of SWAT applications in the upper Nile basin countries. Hydrol. Earth Syst. Sci. 2012, 16, 3371-3381. [CrossRef]

49. Kizza, M.; Westerberg, I.; Rodhe, A.; Ntale, H.K. Estimating areal rainfall over Lake Victoria and its basin using ground-based and satellite data. J. Hydrol. 2012, 464, 401-411. [CrossRef]

50. Yin, X.; Nicholson, S.E. Interpreting annual rainfall from the levels of Lake Victoria. J. Hydrometeorol. 2002, 3, 406-416. [CrossRef]

51. Awange, J.L.; Sharifi, M.A.; Ogonda, G.; Wickert, J.; Grafarend, E.W.; Omulo, M.A. The falling Lake Victoria water level: GRACE, TRIMM and CHAMP satellite analysis of the lake basin. Water Resour. Manag. 2008, 22, 775-796. [CrossRef]

52. Velpuri, N.; Senay, G.; Asante, K. A multi-source satellite data approach for modelling Lake Turkana water level: Calibration and validation using satellite altimetry data. Hydrol. Earth Syst. Sci. 2012, 16, 1. [CrossRef]

53. De Bruin, H.; Keijman, J. The Priestley-Taylor evaporation model applied to a large, shallow lake in the Netherlands. J. Appl. Meteorol. 1979, 18, 898-903. [CrossRef]

54. Allen, R.G.; Pereira, L.S.; Raes, D.; Smith, M. Crop Evapotranspiration-Guidelines for Computing Crop Water Requirements_FAO Irrigation and Drainage Paper 56; FAO: Rome, Italy, 1998; Volume 300, p. D05109.

55. De Bruin, H. From Penman to Makkink. In Proceedings of the Evaporation and Weather: Technical Meeting 44, Ede, The Hague, The Netherlands, 25 March 1987; pp. 5-31.

56. De Graaf, M.; Machiels, M.A.; Wudneh, T.; Sibbing, F.A. Declining stocks of Lake Tana's endemic Barbus species flock (Pisces, Cyprinidae): Natural variation or human impact? Biol. Conserv. 2004, 116, 277-287. [CrossRef]

57. Chebud, Y.A.; Melesse, A.M. Modelling lake stage and water balance of Lake Tana, Ethiopia. Hydrol. Process. 2009, 23, 3534-3544. [CrossRef] 
58. Crétaux, J.-F.; Jelinski, W.; Calmant, S.; Kouraev, A.; Vuglinski, V.; Bergé-Nguyen, M.; Gennero, M.-C.; Nino, F.; Del Rio, R.A.; Cazenave, A. Sols: A lake database to monitor in the near real time water level and storage variations from remote sensing data. Adv. Space Res. 2011, 47, 1497-1507. [CrossRef]

59. Chebud, Y.A.; Melesse, A.M. Numerical modeling of the groundwater flow system of the Gumera sub-basin in Lake Tana basin, Ethiopia. Hydrol. Process. 2009, 23, 3694-3704. [CrossRef]

60. SMEC. Hydrological Study of the Tana-Beles Sub-Basins, Main Report; Snowy Mountains Engineering Corporation: Melbourne, Australia, 2008.

61. Kebede, S.; Travi, Y.; Alemayehu, T.; Marc, V. Water balance of Lake Tana and its sensitivity to fluctuations in rainfall, Blue Nile basin, Ethiopia. J. Hydrol. 2006, 316, 233-247. [CrossRef]

62. Gebremariame, Z.H. Assessment of Climate Change Impact on the Net Basin Supply of Lake Tana Water Balance. Master's Thesis, ITC, University of Twente, Enschede, The Netherlands, 2009. Available online: https://webapps.itc.utwente.nl/librarywww/papers_2009/msc/wrem/zeryehun.pdf (accessed on 6 June 2018).

63. Dargahi, B.; Setegn, S.G. Combined 3D hydrodynamic and watershed modelling of Lake Tana, Ethiopia. J. Hydrol. 2011, 398, 44-64. [CrossRef]

64. Karimi, P.; Bastiaanssen, W.G. Spatial evapotranspiration, rainfall and land use data in water accounting-Part 1: Review of the accuracy of the remote sensing data. Hydrol. Earth Syst. Sci. 2015, 19, 507-532. [CrossRef]

65. Wang, F.; Wang, L.; Koike, T.; Zhou, H.; Yang, K.; Wang, A.; Li, W. Evaluation and application of a fine-resolution global data set in a semiarid mesoscale river basin with a distributed biosphere hydrological model. J. Geophys. Res. Atmos. 2011, 116. [CrossRef]

66. Huang, Y.; Salama, M.; Krol, M.S.; van der Velde, R.; Hoekstra, A.Y.; Zhou, Y.; Su, Z. Analysis of long-term terrestrial water storage variations in the Yangtze River basin. Hydrol. Earth Syst. Sci. 2013, 17, 1985. [CrossRef]

67. Zaitchik, B.F.; Rodell, M.; Olivera, F. Evaluation of the Global Land Data Assimilation System using global river discharge data and a source-to-sink routing scheme. Water Resour. Res. 2010, 46. [CrossRef]

68. Dessie, M.; Verhoest, N.E.; Pauwels, V.R.; Adgo, E.; Deckers, J.; Poesen, J.; Nyssen, J. Water balance of a lake with floodplain buffering: Lake Tana, Blue Nile Basin, Ethiopia. J. Hydrol. 2015, 522, 174-186. [CrossRef]

69. Winter, T.C. Uncertainties in estimating the water balance of lakes. JAWRA J. Am. Water Resour. Assoc. 1981, 17, 82-115. [CrossRef]

70. Neff, B.P.; Nicholas, J. Uncertainty in the Great Lakes Water Balance; 2328-0328; US Geological Survey: Reston, VA, USA, 2005. Available online: https:/ / pubs.er.usgs.gov/publication/sir20045100 (accessed on 6 June 2018).

71. DeMarchi, C.; Dai, Q.; Mello, M.E.; Hunter, T.S. Estimation of Overlake Precipitation and Basin Runoff Uncertainty. International Upper Great Lakes Study, Case Western Reserve University, Cleveland, OH 2009. Available online: http:/ / www.iugls.org/docstore/ProjectArchive/HCL_Hydroclimate/HCL20_DeMarchi_ GLERLComponentNBSUncertaintyAnalysis/Reports/HCL20-R1_DeMarchi.pdf (accessed on 6 June 2018).

72. Wiebe, A.J.; Conant, B., Jr.; Rudolph, D.L.; Korkka-Niemi, K. An approach to improve direct runoff estimates and reduce uncertainty in the calculated groundwater component in water balances of large lakes. J. Hydrol. 2015, 531, 655-670. [CrossRef]

73. Tian, Y.; Peters-Lidard, C.D. Systematic anomalies over inland water bodies in satellite-based precipitation estimates. Geophys. Res. Lett. 2007, 34. [CrossRef]

74. Tang, G.; Long, D.; Hong, Y. Systematic anomalies over inland water bodies of High Mountain Asia in TRMM precipitation estimates: No longer a problem for the GPM era? IEEE Geosci. Remote Sens. Lett. 2016, 13, 1762-1766. [CrossRef]

75. Paiva, R.C.D.; Buarque, D.C.; Clarke, R.T.; Collischonn, W.; Allasia, D.G. Reduced precipitation over large water bodies in the Brazilian amazon shown from TRMM data. Geophys. Res. Lett. 2011, 38. [CrossRef]

(C) 2018 by the authors. Licensee MDPI, Basel, Switzerland. This article is an open access article distributed under the terms and conditions of the Creative Commons Attribution (CC BY) license (http://creativecommons.org/licenses/by/4.0/). 